\title{
SINTEZA COMPONENȚILOR ACTIVI AI FEROMONULUI SEXUAL SINTETIC AL MOLIEI VĂRGATE Anarsia lineatella ZELLER E-5- DECA-5-EN-1-OL ŞI E-5-DECA-5-EN-1-IL ACETAT
}

\author{
Jalbă Svetlana, Odobescu Vasilisa, Erhan Tatiana, Neguţă A. \\ Institutul de Genetică, Fiziologie şi Protecţie a Plantelor, Chişinău, Republica Moldova \\ e-mail:igpppheromones@gmail.com
}

\begin{abstract}
Necesitatea combaterii dăunătorilor culturilor agricole este determinată de faptul că acestea sunt atacate de o gamă largă de dăunatori. Pierderile de recoltă constituie $25-30 \%$, uneori depăşesc 40$50 \%$ sau totalmente compromit recolta. Invaziile de dăunători sunt cauzate de schimbările climaterice, adaptabilitatea acestora şi lipsa unui program complex de combatere. Problema obţinerii culturilor agricole ecologice şi competitive vizează trecerea la o agricultură ecologică şi inofensivă.

Molia vărgată Anarsia lineatella Zeller, este o specie polifagă, care atacă diferite specii de sâmburoase ca piersicul, caisul, vişinul, cireşul, prunul şi migdalul, însă pagube mai mari produce în plantaţiile de piersic. Cercetările privind identificarea compoziţiei feromonului sexual al moliei vărgate Anarsia lineatella Zeller au fost efectuate de către Anthon și colab. în anul 1971, în Washington, SUA. A fost stabilit ca componentele majore, şi ulterior active ale feromonului sexual

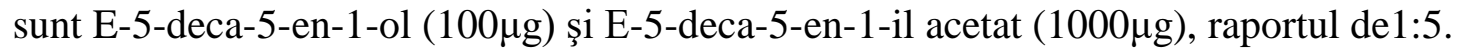

Capcanele cu feromon sexual sintetic al moliei vărgate se folosesc cu succes pentru determinarea numărului şi tipurilor de dăunători, focarele, perioada de zbor, sterilizarea şi captarea în masă a dăunătorilor, precum şi stabilirea cu precizie a timpului de prelucrare chimică sau biologică şi îmbunătăţesc eficacitatea luptei, prin reducerea cu 25-30\% a cantităţii de insecticid.

Astfel, ţinând cont de informaţia ştiinţifică studiată este actuală elaborarea unei metode de sinteză care să îmbine aşa avantaje precum: utilizarea substanţelor iniţiale şi intermediare accesibile, mărirea randamentului produşilor intermediari şi finali, facilitarea purificării în vederea obţinerii produşilor intermediari şi finali cu o puritate de $93-97 \%$ a feromonului sexual sintetic al moliei vărgate, iar preparatul biologic în baza lui poate fi utilizat cu succes în protecţia plantaţiilor de piersic, cais, vişin, cireş, prun şi migdal etc.

Schema de sinteză organică elaborată cuprinde 6 etape de sinteză: deciclizarea tetrahidrofuranului (THF) cu bromură de acetil, reducerea 1-brombutanol-4-acetat-ului cu $\mathrm{LiAlH}_{4}$, protejarea grupei hidroxile cu 3,4-dihidropiran, alchilarea în $\mathrm{NH}_{3}$ lichid cu hexinil-1-litiu, în vederea alungirii catenei, deprotejarea grupe hidroxile, trans-reducere cu Na, terţ-butanol, în $\mathrm{NH}_{3}$ lichid urmată de alchilare cu clorură de acetil în prezenţa piridinei. Substanţele obţinute au fost purificate pe coloana cu silicagel, eluent eter-acetonă şi ulterior a fost analizată puritatea acestora cu ajutorul cromatografiei gaz-lichid.

Substanţele sintetizate E-5-deca-5-en-1-olul şi E-5-deca-5-en-1-il acetatul, reprezintă substanţe lichide, incolore, cu miros specific, cu puritatea de $95 \%$.

Ulterior substanţele sintetizate au fost impregnate pe capsule din cauciuc sintetic, raportul componenţilor de 1:5, în diferite doze: 1, 2 şi $3 \mathrm{mg}$.

Capsulele cu feromon sexual sintetic al moliei vărgate Anarsia lineatella Zeller, au fost fixate de placa cu adeziv entomologic, din interiorul capcanei tip „Delta” şi apoi plasate în câmp, fiind atârnate direct pe copacii de cais şi piersic, în vederea testării activităţii substanţelor şi totodată monitorizării populaţiei de dăunători.
\end{abstract}

